\title{
Treatment of Classical Phenylketonuria
}

\author{
M. S. McBEAN and J. B. P. STEPHENSON \\ From the University Department of Child Health and the Royal Hospital for Sick Children, Glasgow
}

This paper presents some observations on the dietary treatment of phenylketonuric children seen in Glasgow during the past decade. Both the efficacy of the low phenylalanine diet in preventing brain damage (Bessman, 1966), and the adequacy of diagnostic criteria when applied in early infancy (Schneider and Garrard, 1966; Stephenson and McBean, 1967a) have recently been questioned. We therefore feel that it is important to record the interim results of dietary treatment of patients in whom the diagnosis of 'true' or classical phenylketonuria has been formally established (Stephenson and McBean, 1967a). We confirm the value of this treatment but confine our presentation particularly to three topics: the effect of the age when diet is started upon the intellectual result; the effect of good and bad dietary control; and the effect of stopping the diet. These three sets of observations have direct relevance to the treatment of the phenylketonurics that are being diagnosed now, and give additional support to the phenylalanine intoxication hypothesis of Woolf (Woolf and Vulliamy, 1951).

\section{Methods}

Case selection. Dietary treatment was given to all phenylketonuric children presenting under the age of 7 years, except for two institutionalized psychotics, and also to one 10-year-old.

To eliminate all diagnostic uncertainties, only those 31 patients who have been observed until after their first birthday are considered in this report.

Diagnosis. Evidence of severe phenylalanine hydroxylase deficiency persisting beyond the first birthday established the diagnosis in all cases (Stephenson and McBean, 1967a).

Chemical methods. Serum phenylalanine was estimated by the $\mathrm{L}$-amino acid oxidase method of $\mathrm{La} \mathrm{Du}$ and Michael (1960).

Psychometric tests. The type of test varied with the age and development of the child. Infants and those

Received April 17, 1967. of low mental age were usually marked on the Griffiths Scale (or Cattell Infant Scale, in earlier years). The Stanford Binet Scale Form L-M was used for most older children. The Wechsler Intelligence Scale for Children (WISC) was employed in selected cases. An estimate of reading age was made in children of school age on the basis of Schonell's Reading Vocabulary. $95 \%$ of these tests (approximately 100 -including all of those used in the construction of Tables I and II and Fig. 2) were performed by one psychologist.

Low phenylalanine diet. The children were given a low phenylalanine diet as described by Hutchison (1962). This resembled that recommended by the Medical Research Council (1963), except that the low phenylalanine food (Minafen in the infant, Cymorgan in the older child) was given until the serum phenylalanine was normal or subnormal, and then supplemented by known amounts of dietary phenylalanine (e.g. cows' milk) until the blood phenylalanine was stable. Before 1961, negative urine ferric chloride tests and clinical well-being were the only criteria of adequate control in the early stages (six cases).

Vitamin supplements and iron were given to all.

The patients were initially stabilized in hospital, as is the usual practice in Great Britain (Holt, 1963). They were then followed at a phenylketonuria clinic held by one of us (S.McB.) with a dietitian and nursing auxiliary. Visits were usually at intervals of 2 to 4 weeks. At clinic visits, after clinical assessment and growth measurements, time was allowed for discussion of family problems. Dietary adjustments were made in the light of serum phenylalanine estimations: a concentration of $2 \mathrm{mg} . / 100 \mathrm{ml}$. was considered ideal during the treatment years analysed in this paper. Low phenylalanine foods, vitamins, and iron supplements were provided at the clinic. A special low phenylalanine (and gluten-free) loaf $\star$ and low phenylalanine biscuits* have been a boon to older children. Transport to the clinic was provided where necessary.

Psychological testing was carried out at 6-monthly or yearly intervals (occasionally more often).

\section{General Description of Patients}

The 31 treated children derived from 27 families with a total of 74 children, including 2 other presumptive

\footnotetext{
* Prepared by the United Co-operative Baking Society Ltd., Bakery Premises, 12 McNeil Street, Glasgow C.5.
} 
phenylketonurics. They lived in Glasgow or nearby, but in 18 families a grandparent was born in Ireland, and in only 4 families was there neither an Irish grandparent nor an adherence to the Roman Catholic faith.

20 patients received the diet before the age of 3 years, 8 before 3 months. All but 3 children had developed symptoms before treatment was started (vomiting, colic, eczema, psychomotor retardation, seizures, and behaviour problems) (Stephenson and McBean, 1967a).

\section{Results}

Complications and difficulties. Eczema followed phenylalanine deprivation in two infants, but responded to additional dietary cows' milk. One of these (Case 4), the first infant treated, had prolonged phenylalanine deficiency: his case is described later.

The heights and weights of these children clustered about the 25th centile, using the charts of Tanner and Whitehouse (1959), but were probably nearer the normal for the local population. Growth failure occurred in Case 2 between the ages of 6 and 18 months, due in part to overzealous parental restriction of phenylalanine.

After the age of 18 months, several of the children developed a taste for other foods, and raised serum phenylalanine levels were more frequent, sometimes with frank phenylpyruvic aciduria (ferric chloride test). In most cases the hyperphenylalaninaemia resulted from excessive dietary phenylalanine, and would revert to normal during controlled diet in hospital. In the series of Sutherland, Umbarger, and Berry (1966) acute episodic illness contributed to the majority of serum phenylalanine increases, but this was not our experience. The very normality of Case 4, treated from early infancy, led the parents to doubt the diagnosis and abandon the diet.

In 13 of the 27 families there were considerable social or psychological disturbances (including 2 suicide attempts), with chronic physical illness in first degree relatives in 4 families. One mother was understandably unable to cope with three diets (for phenylketonuria, diabetes, and nephrosis) simultaneously, and only 2 of the 5 mothers who had a pair of phenylketonuric children were consistently successful.

\section{Effect of age of starting diet.}

Early infancy. The results of intelligence testing of the 8 children treated from the first 3 months of age are given in Table $I$ and can be compared with the IQ distribution in untreated children in Table II. The mean IQ of the 5 children tested after 2 years of age is 93 .

The number of cases is small, but no correlation is evident between the resultant intelligence and
TABLE I

IQ and Age of Starting Diet

\begin{tabular}{c|c|c|c}
\hline $\begin{array}{c}\text { Case } \\
\text { No. }\end{array}$ & $\begin{array}{c}\text { Age Diet } \\
\text { Started (dy.) }\end{array}$ & $\begin{array}{c}\text { Latest } \\
\text { IQ }\end{array}$ & $\begin{array}{c}\text { Age at } \\
\text { Test (mth.) }\end{array}$ \\
\hline 1 & 11 & 110 & 29 \\
2 & 21 & $73 \dagger$ & 21 \\
3 & 26 & 88 & 58 \\
4 & 47 & 89 & 62 \\
5 & 63 & 79 & 35 \\
6 & 78 & 100 & 43 \\
7 & 78 & $102 \dagger$ & 19 \\
8 & 82 & $105 t$ & 20 \\
\hline
\end{tabular}

* Stanford Binet Form L-M except + .

† Griffiths Quotient.

TABLE II

IQ Distribution in Treated and Untreated Phenylketonurics: Present Series

\begin{tabular}{|c|c|c|}
\hline $\begin{array}{c}\text { IQ } \\
\text { (measured at } \\
2 \text { yr. or over) }\end{array}$ & $\begin{array}{c}\text { Untreated, } \\
\% \text { of } 17 \\
\text { Cases }\end{array}$ & $\begin{array}{l}\text { Treated From } \\
6 \begin{array}{l}\text { Months or Older, } \\
\% \text { of } 23 \text { Cases }\end{array}\end{array}$ \\
\hline $\begin{array}{c}\text { Untestable } \\
0-20 \\
21-40 \\
41-60 \\
61-80 \\
81-\end{array}$ & $\begin{array}{r}6 \\
6 \\
29 \\
47 \\
12 \\
0\end{array}$ & $\begin{array}{r}4 \\
4 \\
26 \\
26 \\
35 \\
4\end{array}$ \\
\hline Total with IQ over 60 & 12 & 39 \\
\hline
\end{tabular}

the age of onset of dietary treatment, within the first three months.

Cases 1 and 6 are normal happy children. Case 4 has somewhat indistinct speech and Cases 3 and 5 have short attention spans. Cases 3 and 4 are holding their own at normal school.

Late childhood. Table II shows the distribution of intelligence (tested at the age of 2 years or over) in children treated from the age of 6 months to 10 years, compared with the untreated children of the same series.

It is evident that the distribution of intelligence among these older treated patients is quite different from that of Cases 1-8 (Table I). Nevertheless, about $40 \%$ have a recent IQ of more than 60 . The improvement in some cases was remarkable, though not confined to IQ changes.

Five examples follow.

Case 21. Girl. Diet from age 35 months. IQ rose from 55 to 114 at age 80 months. Off diet for 7 months. IQ now 96 (age 10 years). Normal school. (See 'Effect of stopping diet'.)

Case 22. Boy. Diet from age 35 months. Progressive increase in IQ from 25 to 62 (age $8 \frac{1}{2}$ years). Graduated from Occupational Centre to Special School.

Case 23. Boy. Diet from age 41 months. IQ from 52 to 61 in 2 years. Stopped diet, and IQ now 77 (age $8 \frac{1}{2}$ years).

Case 25. Boy. Diet from age 67 months. No change in IQ $(63,62)$ but dramatic disappearance of 
noisy psychotic features which had led to expulsion from school.

We have also treated one older child, a girl of $10 \frac{1}{2}$ years (Case 27), who was detected during a survey of special schools (Wilson, Menzies, and Scott, 1966). Fig. 1 demonstrates an advance in her Reading Age from the time of onset of the low phenylalanine diet.

Effect of dietary control. We have determined the distribution of serum phenylalanine levels in each year of treatment of each of our Cases 1-27. (Cases 9 and 10 are not included in this report because observations did not extend beyond the first birthday.) Whichever upper limit of satsfactory control is chosen, it is not possible to demonstrate a correlation between degree of control and resultant intelligence in the children treated after the age of 6 months.

However, we do have some evidence that the degree of dietary control influences the intellectual development of those treated from early infancy. A serum phenylalanine of $12 \mathrm{mg} . / 100 \mathrm{ml}$. has been arbitrarily chosen as a seriously high level (American Academy of Pediatrics, 1965); in fact we found no differences between the patients when using an upper limit of $4 \mathrm{mg}$. $/ 100 \mathrm{ml}$.

Table III shows that by this criterion control was good in the first year, and Griffiths Quotients after this were normal, with the exception of Case 2 . In this child's first year $86 \%$ of the phenylalanine estimations were below $2 \mathrm{mg} . / 100 \mathrm{ml}$. and $50 \%$ below $1 \mathrm{mg} . / 100 \mathrm{ml}$; no other explanation is available for the low IQ which was unchanged at age 21 months.

Only five of the children have had a sufficient further period of diet for analysis, but the data suggest a positive correlation between serum

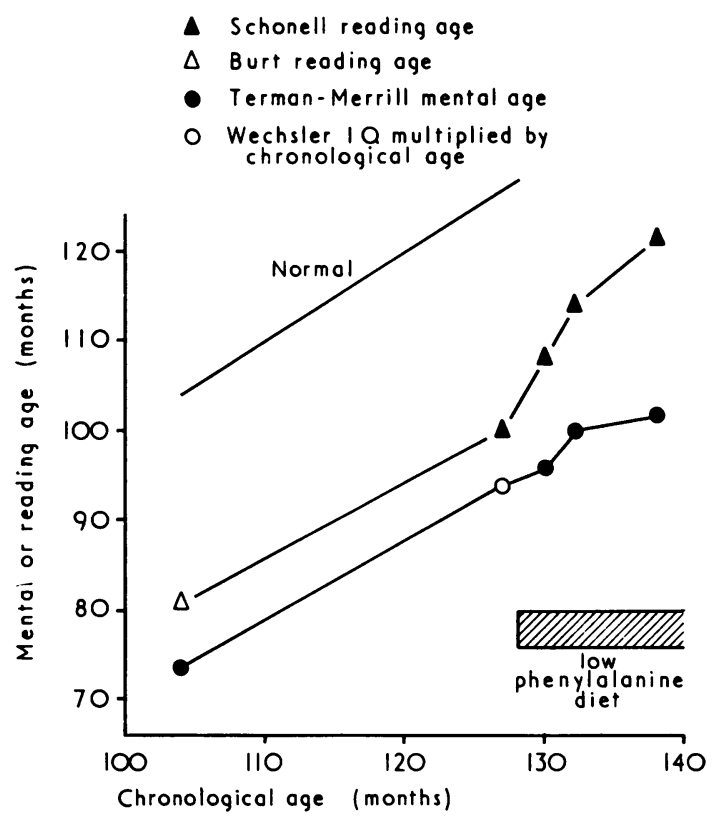

FIG. 1.-Acceleration of reading ability during administration of low phenylalanine diet to a 101-year-old girl (Case 27).

phenylalanine control and resultant intelligence (Table III and Fig. 2).

Effect of stopping diet. We have observed 21 instances of diet breaking in 19 patients. In most cases the IQ was already low and did not change significantly over an observation period of 2 to 3 years. In some instances, there was no change in behaviour either. In Case 25 (see above, Effect of age on starting diet: Later childhood), no

TABLE III

Serum Phenylalanine Control and IQ in First 3 Years

\begin{tabular}{|c|c|c|c|c|c|}
\hline $\begin{array}{l}\text { Case } \\
\text { No. }\end{array}$ & $\begin{array}{l}\text { Age Diet } \\
\text { Started } \\
\text { (dy.) }\end{array}$ & $\begin{array}{c}\text { 1st Year \% } \\
0-12 \text { Serum } \\
\text { Phenylalaninet }\end{array}$ & $\begin{array}{l}\text { Griffiths } \\
\text { Quotient } \\
\text { After Age } \\
12 \text { mth. }\end{array}$ & $\begin{array}{c}\text { 2nd and } 3 \text { rd } \\
\text { Years \% 0-12† } \\
\text { Serum } \\
\text { Phenylalanine }\end{array}$ & Age $3 \stackrel{\mathrm{IQ}^{\star} .}{ } \pm 6 \mathrm{mth}$. \\
\hline $\begin{array}{l}1 \\
2 \\
3 \\
4 \\
5 \\
6 \\
6 \\
7 \\
8\end{array}$ & $\begin{array}{l}11 \\
21 \\
26 \\
47 \\
63 \\
78 \\
78 \\
82\end{array}$ & $\begin{array}{c}\text { Insufficient data } \\
100 \\
83 \\
100 \\
100 \\
100 \\
100 \\
100\end{array}$ & $\begin{array}{r}103 \\
73 \\
103 \\
97 \\
110 \\
91 \\
102 \\
105\end{array}$ & $\begin{array}{c}100 \\
75 \\
<50 \ddagger \\
58 \\
100\end{array}$ & $\begin{array}{c}110 \\
\S \\
84 \\
73 \\
79 \\
100 \\
\S \\
\S\end{array}$ \\
\hline
\end{tabular}

* Stanford Binet Form L-M.

+ Percentage of serum phenylalanine levels maintained in the range $0-12 \mathrm{mg} . / 100 \mathrm{ml}$.

¥ Ordinary diet during 3rd year.

$\S$ Too young. 


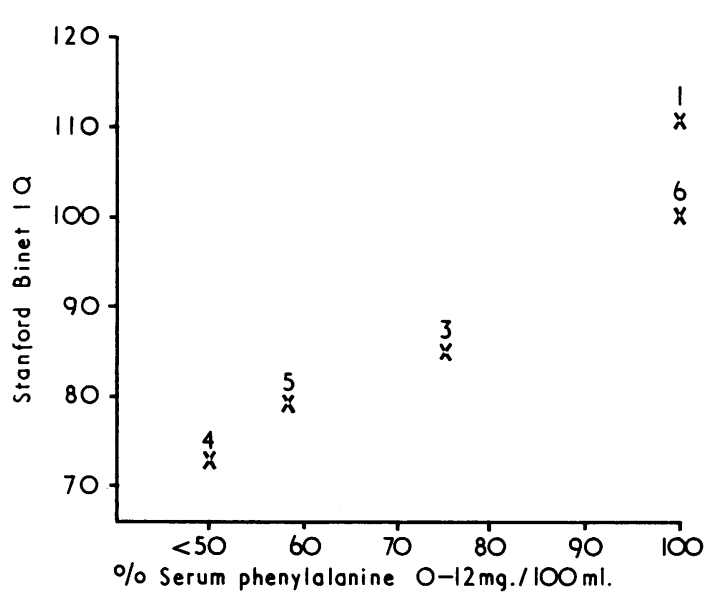

FIG. 2.-Intelligence quotients (Stanford Binet, Form L-M), measured within 6 months of the third birthday, are plotted against the percentage of serum phenylalanine levels falling within the range $0-12 \mathrm{mg} .100 \mathrm{ml}$. during the second and third years of life. The five children started low phenylalanine diet before the age of 3 months. Superscript is case number.

regression towards his previous noisy psychotic state occurred when the diet was discontinued at the age of 9 years; he remains a quiet pleasant boy. Other children with low intelligence have become less placid and biddable, and difficult to manage at home when the diet was stopped as late as at the age of 9 years. One child (Case 23) demonstrated an apparent rise in Stanford Binet IQ from 61 to 77 during 3 years on normal diet from the age of 5 , but he retains a blank expression and has made no reading progress.

Two children deserve further mention because they changed to a normal diet while their intelligence was normal and later returned to a phenylalaninerestricted diet.

The first case history also illustrates so many aspects of the diagnosis and treatment of phenylketonuria that it is presented in some detail.

Case 4: This boy was born in December 1960, weight $4.0 \mathrm{~kg}$., the youngest of three children of Roman Catholic parents of Irish extraction, Social Class V. His father was thought to be below the normal range of intelligence, but the only sib to have an IQ estimation scored 107 at 6 years 10 months (Stanford Binet Form L-M). At 11 days of age a routine napkin-Phenistix test was negative (Stephenson and McBean, 1967b). Vomiting began at 28 days and 12 days later he was admitted to hospital, weighing $3.8 \mathrm{~kg}$. Ferric chloride test on his urine was negative, but the urine was strongly alkaline. A large pyloric tumour was felt, and seen at operation two days later when pyloromyotomy was carried out. Three days after the operation, the ferric chloride test was weakly positive and became stronger over the next 3 days. Two days later, when he was neurologically and developmentally normal, with a serum phenylalanine of $37.1 \mathrm{mg} . / 100 \mathrm{ml}$., he began low phenylalanine diet. Phenylalanine restriction was excessive, and vomiting recurred, with failure to thrive, eczema, and anaemia sufficient to require blood transfusion. At the age of 4 months his Cattell developmental quotient was only 55. After increase in phenylalanine intake there was immediate improvement in general condition, and weight gain. At 10 months of age, his Cattell quotient was 86 and by 18 months his Griffiths quotient was 97 , with consistent results in all scales.

Two months later the first high serum phenylalanine (18 mg./100 ml.), since he had started the diet, was recorded. The parents had decided that the child was normal and did not need the diet. After considerable persuasion, an attempt at phenylalanine restriction was continued for four months, but control was very poor. At the age of 2 years the diet was abandoned: at this stage the child seemed normal in all respects. His serum phenylalanine was $33 \mathrm{mg} . / 100 \mathrm{ml}$. The Stanford Binet IQ was followed carefully.

Each IQ did not differ significantly from the preceding one, but the trend was consistently downwards. At the age of 3 years 2 months his IQ was 73 and he failed all but one of the non-verbal items appropriate for a 21-3 year level. He was facile and hyperactive with short attention span, and impervious to training. He had no sphincter control and habitually smeared himself with faeces. At this stage it was possible to convince his parents that phenylalanine restriction should be restarted, and dietary control has since been excellent (mean serum phenylalanine $3.0 \mathrm{mg} .100 \mathrm{ml}$., $90 \%$ of tests in range $1-6 \mathrm{mg} .100 \mathrm{ml} ., 100 \%$ less than $8 \mathrm{mg} . /$ $100 \mathrm{ml}$.). Mental growth rate increased from then onwards (see Fig. 3). At 6 years 2 months his Stanford Binet IQ has reached 94, but there is evidence of some verbal performance discrepancy (first test failures: folding triangle, copying square; last successes: comprehension, opposite analysis, 'fall in the mud'). $\mathrm{He}$ is a pleasant well-built black-haired boy, holding his own at normal school.

Case 21. This only child, birthweight $2.9 \mathrm{~kg}$., sat alone at 10 months, walked at 17 months, and did not speak till 2 years 7 months. She dribbled constantly from the age of 18 months. At the age of 2 years 11 months her urine ferric chloride test was positive for phenylpyruvic acid. She was still dribbling, had a 'stiff' gait, and easily overbalanced. Her IQ on the Cattell Infant Scale was 55. On low phenylalanine diet (monitored by ferric chloride tests alone) her development accelerated and her abnormal behaviour disappeared. At the age of 4 years 8 months, when her IQ was 78 (Merrill-Palmer), phenylalanine intake was increased from 350 to $2500 \mathrm{mg}$. daily for one week. Her behaviour regressed, with dribbling from the corner 

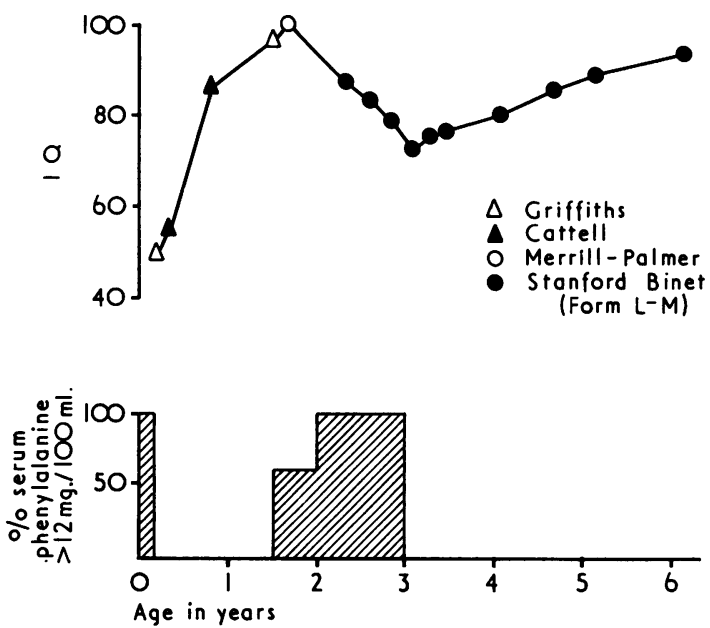

FIG. 3.-The effect of stopping and starting low phenylalanine diet on the intelligence quotient (Case 4). The percentage of serum phenylalanine estimations over $12 \mathrm{mg}$./ $100 \mathrm{ml}$. is indicated by the stippled areas.

of her mouth, change in gait, and abnormal posture: urine $\mathrm{FeCl}_{3}$ test was again strongly positive.

She improved at once on restarting the diet, and was extremely well controlled for the next 2 years (serum phenylalanine range $2 \cdot 0-4.5 \mathrm{mg} . / 100 \mathrm{ml}$.). At 5 years 1 month Stanford Binet IQ was 105, and at 6 years 6 months it was 114 (Table IV). She had some difficulty with arithmetic, but her teacher reported good progress.

She was then taken off the diet (serum phenylalanine $31 \mathrm{mg}$./100 ml.). There was only slight change in her behaviour on this occasion, but her mother thought that her concentration difficulties increased. She was kept back a class at school for the first time. A notable finding was the discrepancy between the verbal (118) and performance (79) scale IQ on the WISC. On Stanford Binet Form L-M she failed some tests which she had passed 8 months previously. In this equivocal situation diet was restarted. There has been little change in her rate of progress, but a gradual reduction in verbal-performance discrepancy has been noted on intelligence testing.

\section{Discussion}

The most important question, which has been posed by Bessman (1966) and Birch and Tizard (1967), is whether phenylalanine restriction can prevent mental retardation in phenylketonurics. Our results with 'true' phenylketonurics suggest that it can, confirming the results of earlier authors (see Lyman (1963) and Knox (1960, 1966) for bibliography, and other references below Table V). The evidence of the first column (' $0-3$ months') of
TABLE IV

Progress of Case 21 Before and After Period of Unrestricted Diet

\begin{tabular}{|c|c|c|c|c|}
\hline Age & $\begin{array}{l}\text { Stanford } \\
\text { Binet IQ }\end{array}$ & $\begin{array}{c}\text { WISC } \\
\text { Full Scale } \\
\text { IQ }\end{array}$ & $\begin{array}{c}\text { WISC } \\
\text { Verbal- } \\
\text { performance } \\
\text { Discrepancy }\end{array}$ & $\begin{array}{l}\text { Schonell } \\
\text { Reading } \\
\text { Age }\end{array}$ \\
\hline $\begin{array}{l}5 \text { yr. } 1 \mathrm{mth} . \\
6 \text { yr. } 1 \mathrm{mth} \text {. } \\
6 \text { yr. } 6 \mathrm{mth} \text {. }\end{array}$ & $\begin{array}{r}105 \\
93 \\
114\end{array}$ & & & $\begin{array}{c}6 \text { yr. } \\
7 \text { yr. } 1 \mathrm{mth} .\end{array}$ \\
\hline \multicolumn{5}{|c|}{7 months on unrestricted diet } \\
\hline $\begin{array}{l}7 \text { yr. } 2 \mathrm{mth} . \\
7 \text { yr. } 8 \mathrm{mth} \text {. } \\
8 \text { yr. } 2 \mathrm{mth} \text {. } \\
9 \text { yr. } 2 \mathrm{mth} .\end{array}$ & 99 & $\begin{array}{r}99 \\
92 \\
101 \\
96\end{array}$ & $\begin{array}{l}39 \\
32 \\
26 \\
23\end{array}$ & $\begin{array}{l}7 \text { yr. } 8 \mathrm{mth} \text {. } \\
8 \text { yr. } 1 \mathrm{mth} . \\
8 \text { yr. } 8 \mathrm{mth} \text {. } \\
9 \text { yr. } 6 \mathrm{mth} \text {. }\end{array}$ \\
\hline
\end{tabular}

Table V-synthesized from published cases and the present series-is quite clear, and is valid even if a few of the published cases were not true phenylketonurics.

The next practical problem concerns the timing of dietary treatment. In his statistical review, Knox (1960) suggested a progressive loss of intellectual potential related to the age at which the diet was begun. Children treated before the age of 16 months fared much better than those treated between 16 months and 3 years. Coates (1961), on the other hand, found no such correlation. The explanation for such discrepancies lies in the number of patients in each series treated before the age of 3 months. Table $\mathrm{V}$ shows this well. It would be of considerable importance to determine whether delay in diagnosis for a few weeks, rather than months, after birth is harmful. For if it were not,

\section{TABLE V}

IQ Distribution in Treated and Untreated Children with Phenylketonuria

\begin{tabular}{|c|c|c|c|c|}
\hline \multirow{2}{*}{$\begin{array}{l}\text { IQ } \\
\text { Measured } \\
\text { Age } 2 \text { Years } \\
\text { or Over }\end{array}$} & \multicolumn{3}{|c|}{$\begin{array}{l}\text { Age Diet Started in } \\
102 \text { Treated Cases* }\end{array}$} & \multirow{2}{*}{$\begin{array}{l}\text { Untreated: } \\
\text { Present } \\
\text { Series, } \\
\% \text { of } \\
17 \text { casest }\end{array}$} \\
\hline & $\begin{array}{l}0-3 \text { mth., } \\
\% \text { of } \\
23 \text { cases }\end{array}$ & $\begin{array}{c}-16 \text { mth., } \\
\text { \% of } \\
35 \text { cases }\end{array}$ & $\begin{array}{c}16 \mathrm{mth} .-3 \mathrm{yr} . \\
\% \text { of } \\
44 \text { cases }\end{array}$ & \\
\hline $\begin{array}{c}0-20 \\
21-40 \\
41-60 \\
61-80 \\
81-100 \\
101- \\
\text { Total with } \\
\text { IQ over } 60\end{array}$ & $\begin{array}{r}0 \\
0 \\
0 \\
18 \\
64 \\
18 \\
100\end{array}$ & $\begin{array}{r}0 \\
23 \\
40 \\
23 \\
11 \\
3 \\
37\end{array}$ & $\begin{array}{l}11 \cdot 5 \\
27 \\
23 \\
25 \\
11 \cdot 5 \\
2 \\
38 \cdot 5\end{array}$ & $\begin{array}{r}6 \\
29 \\
47 \\
12 \\
0 \\
0 \\
12\end{array}$ \\
\hline Mean IQ & $93 \cdot 0$ & $57 \cdot 8$ & $51 \cdot 6$ & $47 \cdot 1 \ddagger$ \\
\hline
\end{tabular}

* Knox (1960); Centerwall, Centerwall, Armon, and Mann (1961b); Coates (1961); Hsia, Rowley, and Raskin (1962); Hsia (1966); Horner et al. (1962); Murphy (1963); Vandeman (1963); Sutherland et al. (1966); Clayton et al. (1966); and present series: latest IQ is recorded when a case is described in more than one publication.

$+6 \%$ untestable.

$¥$ Testable cases. 
this delay might allow an easier separation of the temporary 'phenylketonurics' (Stephenson and McBean, 1967a) from the permanent. No evidence that harm resulted from a few weeks' delay in treatment was found in our series (Table I), but the number of cases is small. The same result was obtained by Sutherland et al. (1966), again with small numbers. In their series all children treated from the first 3 months had normal IQ (100-118): the oldest child tested was 55 months.

Of obvious importance to those concerned with the management of phenylketonuric children is the degree of biochemical control necessary to allow normal development. Bickel and Grüter (1963) advised that the serum phenylalanine-amino oxidase method-should be kept between 0.8 and $1.5 \mathrm{mg}$. $/ 100 \mathrm{ml}$. The Medical Research Council (1963) recommended that the limits should be 1.5 to $4.0 \mathrm{mg} . / 100 \mathrm{ml}$. Umbarger, Berry, and Sutherland (1965) controlled serum levels at 3 to $7 \mathrm{mg}$./ $100 \mathrm{ml}$.-chromatographic method-and tried to keep the urine free from o-hydroxyphenylacetic acid. There is no sound evidence indicating which degree of control is best for the phenylketonuric, but we have shown that the occurrence of serum phenylalanine levels over $12 \mathrm{mg} . / 100 \mathrm{ml}$. is associated with inferior intellectual development. The apparent importance of the second and third years of treatment gives rise to some concern, because at this time of life dietary management is at its most difficult. In early infancy, in addition to avoiding hyperphenylalaninaemia, it may be particularly important to avoid low blood phenylalanine levels, so that temporary 'phenylketonurics' are diagnosed as early as possible and brain damage from phenylalanine deprivation prevented (Stephenson and McBean, 1967a).

The problem of when to stop the diet in phenylketonuria is an agonizing one (Moncrieff, 1964). A number of authors have found little change in the IQ of children allowed ordinary food from early school age or even sooner (Horner, Streamer, Alejandrino, Reed, and Ibbot, 1962; Vandeman, 1963; Murphy, 1963; Solomons, Keleske, and Opitz, 1966; Hsia, 1966), but Centerwall, Centerwall, Acosta, and Chinnock (1961a) warned that a return of features such as irritability and clouding of affect could have an adverse effect on the child's progress even if the IQ did not decrease. Clayton, Moncrieff, Pampiglione, and Shepherd (1966) investigated this problem by observing the change in electroencephalographic patterns during phenylalanine loading tests. One of their most interesting findings was that there were EEG changes during loading in 7 of the children, but little if any in 3 patients treated from the early weeks of life or in 2 older children who had attained entirely normal intelligence. This study did not give a clear answer to the problem of when to stop, but it did hint that the least brain-damaged may be the least susceptible to phenylalanine or its metabolites.

We felt it important to describe in some detail the 2 phenylketonuric children who took normal diet for several months before returning to phenylalanine restriction. The boy (Case 4) showed progressive deterioration on ordinary diet, and progressive improvement on low phenylalanine diet. During each of these periods clinic visits and psychological testing continued, and it is not possible to escape the conclusion that his intellectual growth was related to his dietary control, and not to factors such as mental stimulation, as suggested by Bessman (1966). The girl (Case 21) who has evidence of more subtle brain damage, did not show unequivocal evidence of regression during her second period of normal diet, but the impression of mother, teachers, and psychologist led to the low phenylalanine diet being reinstituted.

In the circumstances, those physicians who firmly believe that the diet should be stopped in the early school years should only allow this in the context of a controlled trial, employing a battery of psychological tests. Others, more conservative, must watch and wait.

We have said little of the treatment of the older phenylketonuric, because if infant screening is successful it should soon cease to be a problem. It is in these patients that more of a case for doubting the effect of treatment can be made, especially when the distribution of intelligence is compared with that of untreated children at home (Table II), rather than with that of institutionalized subjects calculated in retrospect (Paine, 1957). However, in some of our patients from age 3-5 years, improvement has been so remarkable that withholding a trial of the diet from any future children of this age-group is not justified. In one 10-year-old patient (Case 27-Fig. 1) low phenylalanine diet was associated with an acceleration of reading progress, but this may not have been cause and effect. It is in high-grade children of this age-group that controlled trials are in order to determine whether the diet or other factors are responsible for such improvements.

\section{Summary}

The results of dietary treatment of this group of confirmed phenylketonurics is presented. The small number treated from the first three months of life maintained normal intelligence, provided serum phenylalanine control was good. The 
intelligence quotient (IQ) was lower in those whose serum phenylalanine exceeded $12 \mathrm{mg} . / 100 \mathrm{ml}$. after infancy, and also in one child whose serum phenylalanine was less than $2 \mathrm{mg}$. $/ 100 \mathrm{ml}$. during most of his first year. $40 \%$ of children treated after the age of 6 months had a recent IQ of more than 60 (tested at age 2 years or more), contrasted with $12 \%$ of comparable untreated cases. Decline of IQ after stopping the diet at the age of 2 years, and return towards normal after the diet was reinstituted at 3 years, were demonstrated in one child. The results of stopping the diet in older children were variable, but caution is advocated.

The problems of diagnosis, and the meticulous treatment necessary to avoid both phenylalanine excess and deficiency, are such that cases detected by infant screening surveys should be referred to special centres wherever possible.

We thank Professor J. H. Hutchison and Dr. R. A. Shanks for encouragement and criticism; Mrs. Peggy Emerson for psychological testing; and the dietitians of the Royal Hospital for Sick Children, in particular Miss M. F. Whittaker. Dr. A. C. Mallinson kindly prepared the figures.

\section{REFERENCES}

American Academy of Pediatrics (1965). Statement on the treatment of phenylketonuria. Pediatrics, 35, 501.

Bessman, S. P. (1966). Legislation and advances in medical knowledge-acceleration or inhibition? f. Pediat., 69, 334

Bickel, H., and Grüter, W. (1963). Management of phenylketonuria. In Phenylketonuria, ed. F. L. Lyman, p. 136. Charles C. Thomas, Springfield, Illinois.

Birch, H. G., and Tizard, J. (1967). The dietary treatment of phenylketonuria: not proven? Develop. Med. Child Neurol., $9,9$.

Centerwall, W. R., Centerwall, S. A., Acosta, P. B., and Chinnock, R. K. (1961a). Phenylketonuria. I. Dietary management of infants and young children. F. Pediat., 59, 93.

- - Armon, V., and Mann, L. B. (1961b). Phenylketonuria. II. Results of treatment of infants and young children: a report of 10 cases. ibid., 59, 102.

Clayton, B. E., Moncrieff, A. A., Pampiglione, G., and Shepherd, J. (1966). Biochemical and EEG studies in phenylketonuric children during phenylalanine tolerance tests. Arch. Dis. Childh., 41, 267.

Coates, S. (1961). Results of treatment in phenylketonuria. Brit. med. f., $1,767$.
Holt, K. S. (1963). Difficulties and dangers in the management of phenylketonuria. Acta paediat. (Uppsala), 52, 417.

Horner, F. A., Streamer, C. W., Alejandrino, L. L., Reed, L. H., and Ibbot, F. (1962). Termination of dietary treatment of phenylketonuria. New Engl. F. Med., 266, 79.

Hsia, D. Y-Y. (1966). Phenylketonuria: a study of human biochemical genetics. Pediatrics, 38, 173.

- Rowley, W., and Raskin, N. J. (1962). Clinical management of phenylketonuria. Quart. Bull. Northw. Univ. med. Sch., 36, 25.

Hutchison, J. H. (1962). Advances in paediatrics. Practitioner, $189,436$.

Knox, W. E. (1960). An evaluation of the treatment of phenylketonuria with diets low in phenylalanine. Pediatrics, 26, 1 .

- (1966). Phenylketonuria. In The Metabolic Basis of Inherited Disease, ed. J. B. Stanbury, J. B. Wyngaarden, and D. S. Fredrickson, 2nd edn., p. 258. McGraw-Hill, New York.

La Du, B. N., and Michael, P. J. (1960). An enzymatic spectrophotometric method for the determination of phenylalanine in blood. F. Lab. clin. Med., 55, 491.

Lyman, F. L. (1963). Phenylketonuria. C. C. Thomas, Springfield, Illinois.

Medical Research Council (1963). Treatment of phenylketonuria. Brit. med. F., 1, 1691.

Moncrieff, A. (1964). When to stop the diet in phenylketonuria. Develop. Med. Child Neurol., 6, 59.

Murphy, D. (1963). Termination of dietary treatment of phenylketonuria. Irish f. med. Sci., 355.

Paine, R. S. (1957). The variability in manifestations of untreated patients with phenylketonuria. Pediatrics, 20, 290.

Schneider, A. J., and Garrard, S. D. (1966). Diagnostic and therapeutic implications of persistent hyperphenylalaninemia in an infant heterozygous for the gene of phenylketonuria. F. Pediat., 68, 704.

Solomons, G., Keleske, L., and Opitz, E. (1966). Evaluation of the effects of terminating the diet in phenylketonuria. ibid., 69, 596.

Stephenson, J. B. P., and McBean, M. S. (1967a). Diagnosis of phenylketonuria: phenylalanine hydroxylase deficiency temporary and permanent. Brit. med. F., 2, 579.

- , and - (1967b). Phenylketonuria: a reassessment of mass infant screening by napkin test. ibid., 2, 582 .

Sutherland, B. S., Umbarger, B., and Berry, H. K. (1966). The treatment of phenylketonuria. Amer. F. Dis. Child., 111, 505.

Tanner, J. M., and Whitehouse, R. H. (1959). Height and Weight Standard Charts. Printed by Joseph Collard and Sons, London.

Umbarger, B., Berry, H. K., and Sutherland, B. S. (1965). Advances in the management of patients with phenylketonuria. $\mathcal{F}$. Amer. med. Ass., 193, 784.

Vandeman, P. R. (1963). Termination of dietary treatment for phenylketonuria. Amer. F. Dis. Child., 106, 492.

Wilson, T. S., Menzies, M. P., and Scott, J. (1966). Guthrie test for phenylketonuria (PKU): a survey of special schools and occupational centres in Glasgow. Med. Offr, 115, 171.

Woolf, L. I., and Vulliamy, D. G. (1951). Phenylketonuria with a study of the effect upon it of glutamic acid. Arch. Dis. Childh., 26, 487. 